Piotr Niczyporuk

Uniwersytet w Białymstoku e-mail: p.niczyporuk@uwb.edu.pl phone: +48 857457162

DOI: 10.15290/mhi.2014.13.01.01

\title{
Roman Law in Vilnius in the Period of Existence of the Academy of Vilnius
}

\author{
SUMMARY \\ Roman Law in Vilnius in the Period of Existence of the Academy of Vilnius
}

The Vilnius University was established on $7^{\text {th }}$ July 1578, pursuant to the Royal Decree of King Stefan Batory. The royal act of establishment has been confirmed by the papal bull of Pope Gregory XIII on $29^{\text {th }}$ October 1579 and by resolution of the Seym adopted in 1585. Before the rise of the Academy in Vilnius several schools had operated one of them founded by Peter Roizjusz. Thanks to the activity of this famous scholar and lawyer, the elements of Roman law were taught in Vilnius even before the creation of a university in Lithuania. At the beginning of the Academy there were no faculties of law or medicine. Presumably, this was connected with a lack of qualified staff in Lithuania. Only under the privilege granted by King Władysław IV, dated $11^{\text {th }}$ October 1644 was a law faculty opened (composed of a chair of canon law and two of civil law). It is very hard to present a list of professors of Roman law (civil) at the University of Vilnius. Perhaps this is due to the fact that apart from Roizjusz, other scientists interested in Roman Law did not teach in Vilnius. Presumably there was only one chair of civil law (Roman).

There is no doubt that Roman law played an important role in the training of lawyers and was taught intermittently throughout the remaining period of the operation of the Academy. In addition, preserved sources reflect the scientific work of professors, who were employed there. Following the example of other universities, the Academy of Vilnius awarded in this field a combined doctoral degree embracing "both laws" - civil and canon, which applied primarily to future law professors and high-ranking prelates who performed public functions. Probably there were no promoted doctors of civil law. The basis of the lectures were institutions of the Roman law of Justinian, and their content was not different from the standards adopted in other universities.

Key words: Roman law, Academy of Vilnus, Peter Roizjusz

Słowa kluczowe: Prawo rzymskie, Akademia Wileńska, Piotr Roizjusz 


\section{Legal and Educational Activity in Lithuania before the Foundation of the Academy of Vilnius}

The Academy of Vilnius was the first higher education establishment within the territory of the Grand Duchy of Lithuania. Its foundation dates back to the $16^{\text {th }}$ century, which is often referred to in historiography as the "Golden Age" of the Polish-Lithuanian Commonwealth. The Academy of Vilnius was established in the times of civilisation and economic boom in the lands belonging to the Grand Duchy of Lithuania and coincided with the aspirations of its citizens to standardize and rationalize the law ${ }^{1}$. Thus, the second higher education establishment (after the Jagiellonian University) was set up in the Polish-Lithuanian Commonwealth, having influence on the intellectual life of the entire country; a major centre of cultural and academic life of Vilnius, the entire Lithuania and even the neighbouring countries; a bridge connecting the country with other countries of both Eastern and Northern Europe ${ }^{2}$.

The establishment of the Academy of Vilnius was connected with the development of the educational system within the territories of the Grand Duchy of Lithuania. The Jesuit school and Jesuits themselves ${ }^{3}$ undeniably played crucial role for the future Vilnius University. Until the arrival of Jesuits in Lithuania, neither Vilnius nor the entire country had a higher education establishment ${ }^{4}$.

1 S. Godek, Prawo rzymskie w dawnej Rzeczypospolitej. Przegląd stanu badań, CPH 53 (2001), z. 2, page 48 and others, idem: Prawo rzymskie w Polsce przedrozbiorowej w świetle aktualnych badań, Zeszyty Prawnicze 13.3 (2013), pp. 39-64. For many years, the University remained the only higher education establishment in Lithuania - A. Šidlauskas, Zarys historiografii Uniwersytetu Wileńskiego, Studia z dziejów Uniwersytetu Wileńskiego 1579-1979, ZN UJ 554 Prace Hist. (1979), z. 64, page 11.

2 P. Niczyporuk, Nauczanie prawa rzymskiego w Akademii Wileńskiej [in:] Wielokulturowość polskiego pogranicza. Ludzie - Idee - Prawo. Materiały ze Zjazdu Katedr Historycznoprawnych Augustów 1518 września 2000 r., edited by A. Lityński and P. Fiedorczyk, Białystok 2003, page 145 et seq.; idem, Преподавание римского права в Вильнюсской Академии [in:] Зборник радова Правног факултета у Новом Саду. Recueil des travaux XXXVIII, 1, t. I (2004), IX Колоквиј Романиста Централне и Источне Европе и Азије, Нови СаА 24 октобра 2002, Нови Сах 2004, page 203 et seq.; idem, Predarea dreptului roman la Universitatea din Vilnius [in:] Ad honorem Prof. univ. dr. Ion Dogaru: studii juridice alese / volum coordonat de prof. univ. dr. Adrian Năstase; traducera Adriana Uliu; Bucureşti 2005, page 583 .

3 At the prompting of Augustyn Rotundus Mieleski, the mayor of Vilnius, with the support of the Radziwiłł voivode, approval of King Sigismund August and the aid of one the of the leaders of the Council of Trent (Hosius - the Bishop of Warmia), active defenders and advocates of Catholicism were brought to Vilnius. Faith was pinned upon them that they would finally crush the infidels, among whom Calvinists were considered the most dangerous. Jesuits were perceived to be an effective tool both in the fight with the opponents of Catholicism and in the process of conversion, which is why their favour was sought so much. See J. Bieliński, Uniwersytet Wileński (1579-1831), t. II, Kraków 1900, page 476. Nevertheless, Jesuits came to Lithuania, first of all, owing to the efforts of Walerian Protasewicz, Bishop of Warmia. See M. Baliński, Dawna Akademia Wileńska, Petersburg 1862, pages 24-25; L. Janowski, Historiografia Uniwersytetu Wileńskiego, cz. 1, Wilno 1921, page 8 .

4 J. Bieliński, op. cit., t. I, pages 23-24. 
By that time, Vilnius had had no rich academic background or an expanded educational system. schools, but lessons were limited to reading, writing and basic arithmetic ${ }^{5}$.

The oldest and the most important academic centre was the cathedral school, probably set up under the rule of King Casimir IV Jagiellon ${ }^{6}$. There were also two other higher education establishment in Vilnius at the time, namely, the Calvin school, established in 1529 by Abraomas Kulvietis, and the St John's school founded in 15637. The initiator of the foundation of the school at St John's Church was Pedro Ruiz de Moroz, a Spanish lawyer and professor at the Academy of Cracow, educated in Bologna". The activity of the "Spanish Doctor" in Lithuania started in $1551^{9}$ and was provoked by his numerous

5 Ibidem, page 475. Gentry used the educational services rendered by bachelors who, unfortunately, were incompetent and not very well prepared to teach - M. Baliński, op. cit., page 26. Next to the academic establishments like the schools mentioned, there were also inventories of the main cities and historical monuments in the form of manuscripts. The schools founded "at colleges and cathedrals are also worth noting. In such schools, young people were prepared to work in education and to become priests" - J. Jaroszewicz, Obraz Litwy pod względem jej cywilizacji od czasów najdawniejszych do końca wieku XVI, Wilno 1844, t. II, pages 78-79.

6 The school was reformed in 1522 by Jan, the Duke of Lithuania, the then Bishop of Vilnius. The task of reforming the school was taken up by Jakub Staszewski, canon priest of Cracow. From then on, the level of the school was adequate and focus was put on the discipline of students (scholares arcenses), who were admitted for a certain fee. Moreover, the school had a special privilege: no other schools could be established or run in the city without its permission. See: M. Baliński, op. cit., page 26; J. Bieliński, op. cit., t. II, page 475; J. Wisłocki, Prawo rzymskie w Polsce, Warszawa 1945, page 52 - In 1603, the function of the vice-chancellor of the school was performed by an outstanding lawyer, Stanisław Gałązka.

7 J. Wisłocki, op. cit., page 52. Although, using the privilege granted, the cathedral school did not give permits for opening new schools, it had to make an exception for the school in Vilnius. Nevertheless, there were several factors conditioning the granting of the permit: the school was obliged to educate six boys fit for the choir and sixteen other boys - twenty two students in total. Since there are traces indicating that law was lectured in the school and, as is generally known, Moroz was an outstanding lawyer, an eminent expert both in Roman law and domestic law (land and city privileges), it is believed that he taught in the school as professor of law. See: J. Bielinski, op. cit., t. II, page 475 .

8 P. Moroz - born in Alcaniz, Aragon. Left for Lerida and then studied law in Bologna. Arrived in Poland, brought here by Gamrat. For 10 years, Moroz taught Roman law at the academy of Cracow. See: B. Kruczkiewicz, Royzyusz. Jego żywot i pisma, Rozprawy Wydziału Filologicznego Akademii Umiejętności w Krakowie 27 (1897), page 5 et seq.; idem, De Royzii vita operibusque, [in:] Petri Royzii Maurei Alcagnicensis Carmina, Pars I. Carmina maiora continens, ed. B. Kruczkiewicz, Cracoviae 1900, page IX et seq.; G. Bukowska, Tomasz Drezner, polski romanista XVII wieku i jego znaczenie dla nauki prawa w Polsce, Warszawa 1960, page 47; Bibliografia Literatury Polskiej - Nowy Korbut, t. III. Piśmiennictwo Staropolskie, drawn by R. Pollak, T. Witczak, D. Maniewska, J. Cybertowicz, Warszawa 1965, page 176 et seq.; J. Tazbir, Piotr Roizjusz, [in:] Polski Słownik Biograficzny, chief ed. H. Markiewicz, t. XXXI, Wrocław 1988-1989, page 499 et seq.; M. Dyjakowska, Prawo rzymskie w Akademii Zamojskiej w XVIII wieku, Lublin 2000, page 28; J. Sondel, Zawsze wierny. Uniwersytet Jagielloński a Kościół rzymskokatolicki, Kraków 2006, page 127 et seq.

9 A. Tamošiūnienè, Pilietiškumas Petro Roizijaus ( 1505-1571) kūryboje, unpublished doctoral thesis, Kaunas 2007, page 52). In the opinion of T. Fijałkowski, Pedro Ruiz de Moroz moved to Vilnius c.a. 1552 (T. Fijałkowski, Piotr Rojzjusz - polski romanista XVI wieku, [in:] Z dziejów polskiej kultury 
obligations at the royal court ${ }^{10}$, as well as by his holding of an ecclesiastical office $^{11}$. T. Fijałkowski was of the opinion that the Doctor's relocation to Vilnius resulted from his appointment to perform the function of the royal court assessor $^{12}$. Moroz was also known - not only for his contribution to posterity - but for his poetic work and his epitaphs gained recognition of the contemporary. However, at the core of his activity lay law. His academic output and practice as a lawyer constitutes proof that the tradition of Roman law in Vilnius is older than the University ${ }^{13}$.

It was in Vilnius, that Pedro Ruiz de Moroz wrote his Decisiones, one of the greatest classical works of the 'old' Poland ${ }^{14}$. It was the result of his judicial practice, studies and theoretical deliberations. Decisiones contains in its wording five judicial orders, analysed in detail and provided with precise comment. Thus, it serves as a gloss to the activity of the assessor court in Vilnius, in which Pedro Ruiz de Moroz had a seat ${ }^{15}$. However, there are no reliable sources which would allow to view Moroz not only as the codifier but as

umystowej w XVI i XVII wieku, W. Voisé (ed.), Wrocław-Warszawa-Kraków-Gdańsk, page 10). See: A. Tamošiūnienè, Eiless lediniam kraštui. Sarmatijos paveikslas Petro Roizijaus poezijoje, Darbai ir Dienos 44 (2005), page 151 et seq.

10 In October 1st 1549, Pedro Ruiz de Moroz was appointed the king's legal adviser. He used to sit in Polish and Lithuanian tribunals for the matters of the city. Cf. T. Fijałkowski, Piotr Rojzjusz polski romanista XVI wieku, cit. s. 10 et seq.

11 At the end of 1566 and the beginning of 1567, he was appointed by the monarch the Archpriest at St. John's Church in Vilnius. Soon, he received further promotions. He was the Kroże parish priest and the canon priest of Samogitia. In October 1567, he became the Vilnius canon priest and in August 1569, the Vilnius cathedral custodian. Never ordained a priest. Throughout his ministry, he received the canon salary although being only a deacon. This might signify his high rank. See: M. Nowodworski, Encyklopedia kościelna, Warszawa 1899, t. XXIII, page 445 et seq.; T. Fijałkowski, Piotr Rozjusz - polski romanista XVI wieku, cit., page 9 et seq.; M. Dyjakowska, op. cit., page 28.

12 It was connected with the monarch's stay in Vilnius. Cf. B. Kruczkiewicz, op. cit., page 40 et seq. T. Fijałkowski stated that Moroz was appointed assessor under the royal decree issued in Cracow on May $29^{\text {th }} 1549$. He received a salary of 500 florins. Among the materials on the history of writing is a decree by King Sigismund August concerning Pedro Ruiz de Moroz, issued in Cracow on May 29 $9^{\text {th }}$ 1549: "Annuta pensio Petri Roysii Maurei in zuppis Wieliciensibus" - see. Materyaty do dziejów piśmiennictwa polskiego i biografii pisarzów polskich, zebr. T. Wierzbowski, t. I. 1398-1600, Warszawa 1900, page 106, item 166.

13 J. Kodrębski, Prawo rzymskie w Polsce XIX wieku, Łódź 1990, page 32.

14 Decisiones de rebus in sacro auditorio Lituanico ex appelatione iudicatis - first edition - Kraków 1563, second edition - Frankfurt am Main 1570, third edition - Venice 1572. See: J. Kodrębski, op. cit., page 16. Cf. T. Fijałkowski is of the opinion that Decisiones did not play a major role in the shaping of the legal awareness of an enlightened society. See: Piotr Rozjusz w opiniach wspótczesnych i potomnych, Sprawozdania z Czynności i Posiedzeń Łódzkiego Towarzystwa Naukowego 26.5 (1972), page 6.

15 The work suggests a thorough classical education of the author and excellent knowledge of medieval lawyers, commentators in particular. In his comments, Pedro Ruiz de Moroz used mainly extracts from Corpus Iuris Civilis and other Roman law sources. He referred to German law, canon law and Polish law and used abundant legal literature. 
the creator of the Lithuanian school of law as well ${ }^{16}$. Nevertheless, although never stated expressis verbis, it is highly probable that he participated in the works on the Second Statute of Lithuania ${ }^{17}$. What is known for sure is that the impact of Roman law on the law of the Grand Duchy of Lithuania was indisputable, a fact that has been confirmed by numerous researchers ${ }^{18}$.

Pedro Ruiz de Moroz was also an efficient organizer and reformer of education. He reformed the educational system in the school at John the Baptist Church in Vilnius, which he elevated into an "Academy"19. Moreover, he elaborated the collection of rights and privileges of the cathedral church in Miedniki. As the archpriest of St. John's Church, he reformed the parish school introducing thereto teachings on Roman law, the Statute of Lithuania and Greek ${ }^{20}$. The aforementioned school of law probably existed until 1570, that is, until the first Jesuit gymnasium was founded ${ }^{21}$. Moroz carried out educational activity, holding lectures on Roman law in the cathedral school of Vilnius. As there are no sources available, we are unable to list the textbooks used by him. Presumably, in his classes he passed practical knowledge in the manner presented in Decisiones. It is owing to the activity of this renowned academic and lawyer that the elements of Roman law had been taught in Vilnius even before the foundation of a school of higher education. Through his activity, Pedro Ruiz

16 J. Bardach, Statuty litewskie w ich kręgu kulturowym, [in:] O dawnej i niedawnej Litwie, Poznań 1988, page 32.

17 I. Lappo, Litowskij statut 1588 goda, t. I, part 2, Kowno 1936, page 81-89; T. Fijałkowski, Piotr Rozjusz - polski romanista XVI wieku, op. cit., page 11 et seq.

18 O. Balzer, Przygodne słowa, Lwów 1927, pages 189-196; S. Estreicher, Kultura prawnicza w Polsce XVI wieku, [in:] Kultura staropolska, Kraków 1932, pages 73-74; R. Taubenschlag, Wpływy rzymskobizantyjskie $w$ drugim Statucie litewskim, Lwów 1933, idem, Gli influssi romano-bizantini sul secondo Statuto lituano, SDHI 1 (1937), pages 42-62; idem, La stiria delle recezione del diritto romano in Polonia fino alla fine del secolo XVI, Bolonia 1939, reprint [in:] Europa e il Diritto Romano. Studi in memoria di Paolo Koschaker, t. I, Milano 1953 (1954), pages 227-242, idem, Eiflus der römischen Rechts in Polen, [in:] Ius Romanum Medii Aevi, c. 5, 1962, no. 7-9; F. Bossowski, Nowela Justyniana 115 - Statut Litewski i R. IV. Art. 13 (14), Statut Litewski II i III R. VIII Art. 7 - T. X. Cz. I Art. 167, [in:] Księga pamiątkowa ku uczczeniu czterechsetletniej rocznicy wydania pierwszego Statutu litewskiego, ed. S. Ehrenkreutz, Wilno 1935, pages 107-121; S. Ehrenkreutz, Zagadnienia wptywu prawa rzymskiego na Statuty litewskie, [in:] Pamiętnik VI Powszechnego Zjazdu Historyków Polskich w Wilnie, t. I, Referaty, Lwów 1935, pages 188-196; I. Lappo, op. cit., pages 81-89; A. Vetulani, Opory wobec prawa rzymskiego w dawnej Polsce, "Analecta Cracoviensia", t. I, 1969, pages 383-384; J. Bardach, Statuty litewskie w ich kreggu kulturowym, cit., pages 9-71; idem, Geneza romanizacji II Statutu litewskiego, [in:] Dawne prawo i myśl prawnicza (poświęcone pamięci Wojciecha Marii Bartla), Kraków 1995, pages 191-206; idem, Statuty Litewskie a prawo rzymskie, Warszawa 1999; S. Godek, op. cit., page 48 et seq. together with the literature quoted therein.

19 M. Baliński, op. cit., page 27; S. Załęski, Jezuici w Polsce, t. I, part 1, Kraków 1900, page 179 et seq.

20 I. Lappo, op. cit., page 86-88; J. Bardach, Statuty litewskie w ich kreggu kulturowym, cit., page 32;

S. Godek, op. cit., page 49.

21 J. Bieliński, op. cit., t. II, page 475. 
de Moroz laid foundations in Lithuania for the future academy ${ }^{22}$. Vilnius became the cultural and educational centre that bloomed in the period of Reformation and Counter-Reformation ${ }^{23}$.

In the $16^{\text {th }}$ century, Jesuits were brought to Lithuania and started their educational activity there. On August $18^{\text {th }} 1570^{24}$, Walerian Protasewicz, Bishop of Vilnius, established a Jesuit College in the city ${ }^{25}$. The college was one of many founded by Jesuits within the territory of the Grand Duchy of Lithuania, and its first vice-chancellor was Stanisław Warszewicki ${ }^{26}$. Papal bulls issued by consecutive popes: Paul III (1549), Julius III (1550 and 1552), Pius IV (1561), Pius V (1571) and Gregory XIII (1575) allowed Jesuits to freely establish schools and run the educational system within the entire territory of Lithuania ${ }^{27}$.

\section{Foundation of Academia et Universitas Vilnensis}

Academia et Universitas Vilnensis was not built from scratch but created as a result of transformation of a Jesuit college ${ }^{28}$. Until the time of its transformation into the Vilnius Academy, the Jesuit college had existed for almost nine years and laid the foundations for the future university ${ }^{29}$.

The Jesuit school was granted the rights of a university pursuant to the privilege issued by King Stephen Bathory on July $7^{\text {th }} 1578^{30}$. The royal charter was confirmed by the papal bull of Pope Gregory XIII dated October $29^{\text {th }} 1579$

22 The conflict which arose between Pedro Ruiz de Moroz, in his declining years, and Jesuits concerning St. John's Church in Vilnius, is commonly known. See: T. Fijałkowski, Piotr Rozjuszpolski romanista XVI wieku, cit., page 12 et seq.

23 D. Beauvois, Szkolnictwo polskie na ziemiach litewsko-ruskich 1803-1832, t. I, Uniwersytet Wileński, Rzym - Lublin 1991, page 18. Cf. A. Jobert, Luther à Mohyla, Paryż 1974, page 241 et seq.

24 Z. Skubała-Tokarska, Z. Tokarski were of the opinion that it was founded in 1569 (Uniwersytety w Polsce. Rys historyczny, Warszawa 1972, page 68).

25 K. Puchowski, Jezuickie kolegia szlacheckie Rzeczypospolitej Obojga Narodów: studium z dziejów edukacji elit, Gdańsk 2007, page 319 et seq.

26 See: J. Jaroszewicz, op. cit., page 85; V. Lyavshuk, Stephan Bathory and the Jesuits in Grodno: First Attempt to Found a Collegium, Medieval and Early Modern for Central and Eastern Europe 2 (2010), page 207, note 71 .

27 S. Bednarski, op. cit., page 290.

28 K. Puchowski, op. cit., page 319 et seq.

29 Owing to the generosity of founders, it was possible to erect the buildings and create chairs and gymnasium classes. The intensification of preparations to open the doors and gates of the university took many years in the period of existence of the Jesuit school and formed a good organizational and material basis for the transformation of the college into the Vilnius Academy. See: S. Bednarski, Dwieście lat Wileńskiej Akademii Jezuickiej 1570-1773. Próba syntezy [in:] Pamiętnik VI Powszechnego Zjazdu Historyków Polskich w Wilnie 17-20 września 1935 r., t. I, Lwów 1935, page 290.

30 V. Lyavshuk, op. cit., page 196. 
and by a resolution of the Sejm adopted in $1585^{31}$. There is a difference between the wording of the royal privilege and the papal bull, which had a significant impact on the structure of the Academy of Vilnius. The royal foundation act provided for the existence of the following faculties: philosophy with the chairs of metaphysics, logics, ethics, mathematics, history and geography, canons and theology. It is beyond doubt that the latter was considered a priority. Within the scope of the faculty of theology, lectures were to be held on moral and dogmatic theology, the Holy Bible - the Old and the New Testament, case law and the history of the Church ${ }^{32}$. Therefore, the structure of the Academy of Vilnius could correspond to the customarily adopted organizational structure of Jesuit higher education establishments, within which there were only three faculties ${ }^{33}$. But such argument is not convincing, as the reasons for shaping such organizational structure of an academy/university are unknown.

There is no doubt that the royal foundation act did not stipulate the possibility to introduce law and medicine into the Academy of Vilnius. "(...) in Collegia Vilnensi non in Iure Civili, sed in Artibus et Philosophia ae Theologia promotiones (...) faciendae ${ }^{\prime 34}$. Many a researcher suggested that behind the lack of these faculties in the structure of the university lay the fact that Jesuits considered the Academy a clerical school ${ }^{35}$. And there is no doubt that the Society of Jesus managed the university until the Order was dissolved. Thus, from the very beginning of its existence, the newly established Academy of Vilnius was a clerical school. Perhaps this is why, from the start, the helm of the university was entrusted to Jesuits. The first vice-chancellor from the Society of Jesus, Piotr Skarga, was an eminent preacher and a brilliant observer of the political life of Rzeczpospolita ${ }^{36}$. Certainly, behind the idea to establish the Academy of Vilnius rested both the need to fight against the infidels harassing Catholicism and the desire to possess the University which had such a great influence on intellectual life in the entire country and was the cradle of culture, science and education. Nonetheless, the willingness to educate the young in a Catholicspirited way does not constitute sufficient grounds for the reluctance to teach law and medicine on the part of the Society of Jesus. Therefore, it is difficult to fully agree with the opinion of J. Jaroszewicz that "the royal charter permitted the award of all academic degrees, that is, bachelors, masters and

31 S. Bednarski, op. cit., page 290. See: także: L. Janowski, op. cit., page 8; J. Wisłocki, op. cit., page 52 .

32 L. Janowski, op. cit., page 8. See also: J. Bieliński, op. cit., t. III, page 3.

33 S. Bednarski, op. cit., page 291.

34 See: J. Wisłocki, op. cit., page 52.

35 J. Bieliński, op. cit., t. II, page 475 et seq.

36 More on Skarga, see: N. Davis, Boże igrzysko. Historia Polski, Kraków 1997, t. I, page 395-398, together with the literature quoted therein. 
doctors of liberal arts, philosophy and theology, with the exclusion of civil law and medicine, on an explicit demand of Jesuits. Not only were both sciences considered (...) less important, as they were of no aid in the propagation of faith, but also inappropriate since, in accordance with canons and case conferences, they could not be lectured by clerics." ${ }^{\prime 37}$. The point of view expressed by S. Bednarski that "in principle, Jesuit universities had only three faculties, atrium, philosophy and theology, yet, still, they did not exclude the existence of law and medicine - provided that such faculties were run by lay professors and had their own foundations" ${ }^{\prime 38}$. Quoting the work by J. Załaszowski, Ius Regni Poloniae, A. Šidlauskas states that the Academy of Vilnius was refused the status of a university strictly because of the lack of medicine and law and inadequate number of chairs. He also quotes the remarks by Jan (Joanes) Preuschhoff - polemical with regard to Załaszowski's opinion (Universitas Vilnensis Jagiellonico-Batoreana, laurearum academicarum florida... Vilnae 1707), who tries to defend the Academy's right to obtain the status of a university ${ }^{39}$. It can be stated that Jesuits did not plan beforehand on cutting down the educational offer of the Academy. Thus, one cannot charge the authorities of the Society of Jesus with not taking into consideration the rank of the establishment which they founded and ran, since such deliberate strategy could deprive the academy the rights of a university ${ }^{40}$. Finally, the lack of the faculties of medicine and law within the structure of the Academy cannot be justified with preparatory actions aiming at the foundation, together with the Academy of Cracow, of one big clerical school ${ }^{41}$.

On the other hand, in his disquisitions to the letter by Mutio Vitelleschi - superior general of the Order, to Augustine Vivaldi - provincial superior, L. Piechnik refutes the conviction of the majority of historians concerning the Jesuits' reluctance to open the faculties of law and medicine ${ }^{42}$. Additionally, he points to differences in the wording of the Almae Matris foundation deeds, that is, of the royal and the papal documents ${ }^{43}$. Piechnik indicates that the privilege granted by King Stephen Bathory expressly refused the Academy the right to grant any academic degrees in law and medicine. Such ban was

37 J. Jaroszewicz, op. cit., page 91-92: “(...) Z liczby nauk w nowej Akademji wykładać się mających w pierwszym zaraz przywileju Stefana Batorego wyraźnie Prawo i Medycyna wyłączone zostały" (Of the sciences of the new Academy, which were to be lectured in accordance with the first privilege granted by Stephen Báthory, Law and Medicine were excluded explicitly.)

38 S. Bednarski, op. cit., page 291.

39 A. Šidlauskas, op. cit., page 13.

40 Ibidem.

41 J. Bieliński, op. cit., t. II, page 475-476; J. Jaroszewicz, op. cit., pages 91-92.

42 L. Piechnik, Dzieje the Academy of Vilnius, t. II: Rozkwit Akademii Wilenskiej w latach 1600-1655, Rzym 1982, pages $158-159$.

43 L. Piechnik, op. cit., t. II, page 157. 
not mentioned in the papal bull, which permitted teaching not only theology, philosophy and liberal arts but also "what constitutes the subject of general university studies in Poland and in other Christian kingdoms"44.

It is possible that behind the lack of the legal and medical faculty at the newly-established university lay organizational factors. The Academy itself was not prepared to launch lectures on law and medicine. However, efforts were made in this scope.

\section{Establishment of the Faculty of Law at the Academy of Vilnius}

The efforts of many years' standing to establish the faculty of law were crowned with success in the 1640s. This was owing to the commitment and financial aid of the then vice-chancellor of the Grand Duchy of Lithuania, Kazimierz Lew Sapieha, who provided relevant funds ${ }^{45}$. On the basis of the privilege issued by King Ladislaus IV on October $11^{\text {th }} 1644$, the faculty of law was opened with two chairs of canon law and two chairs of civil law" cedimus ut in praenominata Akademia Vilnensi Societatis Jesu Ius Canonicum ae Civile et Medicina publice praelegi possint, et ut quiennque digni iudicati fuerint in eisdem omnibus facultatibus ... promoveri valeant ad gradus omnes in aliis Academiis et Universitatibus solitos conferri" ${ }^{47}$. In accordance with the literal wording

44 M. Baliński, op. cit., pages 428-429.

45 The founder handed 12,500 florins to Benedictus de Soxo. A certain percentage of this amount was to be divided between four professors. Sapieha undertook in writing to provide an additional 25,000 florins. A percentage thereof was to be handed to two lay professors who, in addition to their salary, received several hundred florins per year from the founder to pay their accommodation. J. Łukaszewicz, (Historia szkót w Koronie i w Wielkim Księstwie Litewskim od najdawniejszych czasów aż do roku 1794, t. IV, Poznań 1851, pages 24-26) calculated that a professor-Jesuit received a salary amounting to $6 \%$ per year (187.50 Polish zlotys) while a jurist received 937 Polish zlotys. In 1655, the founder allocated his property in Poczajowice (Orsza poviat) to secure financially the faculty of law. Income on the property allowed to maintain four professors and build a house for lay lecturers plus new premises for the faculty of law (L. Piechnik, op. cit., t. II, page 176-177). Speaking of civil law, we mean Roman law, as no domestic law was lectured then at all.

47 J. Wisłocki, op. cit., page 52. See also: S. Bednarski, op. cit., page 291; L. Janowski, op. cit., page 9. Polish translation by J. Bieliński, op. cit., t. II, page 476: “Tym naszym pismem zezwalamy, aby na wspomnianej uprzednio Akademii Wileńskiej Towarzystwa Jezusowego mogły się publicznie odbywać wykłady z zakresu prawa kanonicznego, cywilnego i medycyny i żeby ci, którzy na jakikolwiek z tych wydziałów uznani zostaną za godnych, mogli być dopuszczeni za zgodą rządzącego aktualnie rektora Kolegium i Akademii tego Towarzystwa do wszystkich stopni, jakie zwykły nadawać inne akademie i uniwersytety..." (By this letter we express our consent for the aforementioned Academy of Vilnius of the Society of Jesus to hold public lectures on canon law, civil law and medicine and agree that those who are considered worthy admission to any of the faculties should be allowed to be granted - upon the consent of the currently ruling vice-chancellor of the College and Academy of the Society of Jesus - all degrees awarded by other academies and universities...). 
of the foundation documents, it was also decided to establish the faculty of medicine, but wars with Sweden affected organizational changes at the Vilnius Academy, which had to be postponed in time.

The foundation of the faculty of law dates back to 1644 . It should be noted that the history of the faculty is older, as L. Piechnik stated referring to the manuscripts found and, in particular, to the chronicles of the college in Kroże ${ }^{48}$. In accordance with the manuscripts, first traces of the pursuits to establish the faculty of law were found in $1618^{49}$. Organizational discrepancies and, first of all, the location of the future faculties within the structure of the Academy of Vilnius lay behind the postponement of the organizational efforts inside the establishment.

In 1641, the attempts to expand the Almae Mater in Vilnius by the faculty of law were made again, as further development and extension of Academia Vilnensis was an important issue, which won the favour and approval of the contemporary ${ }^{50}$.

The proposal to open the faculty of law with two chairs of canon law and two chairs of civil (Roman) law was put forward by the then provincial superior of the Grand Duchy of Lithuania, Jan Jamiołkowski supported, first of all, by Jan Grużewki, the vice-chancellor of the Jesuit school of higher education ${ }^{51}$.

48 As Piechnik says, the documents were retrieved by P. Rabikauskas, a Lithuanian historian (Teise ir medicina Vilniaus Akademijoje, Aidai 3 (1975), p. 97-112) - L. Piechnik, op. cit., t. II, page 157.

49 The then Lithuanian vice-chancellor and the starost of Samogitia rolled into one, Hieronim Wołłowicz, decided to expand the Vilnius higher education establishment by two faculties: law and medicine. He presented his idea to the vice-chancellor of the Academy of Vilnius and to the superior general of the Order, Mutius Vitelleschi. The superior general of the Order proved to be highly cautious and distanced with regard to the implementation of the plan, although other Jesuits were very favourably inclined towards the idea of the vice-chancellor. The Order's superior did not question the need to expand the Academy by new faculties, but had organizational remarks concerning the project. In his organizational efforts, Hieronim Wołłowicz followed the example of the Jesuit university in Parma, within the structures of which new faculties were opened and the vice-chancellor of which was Augustine Vivaldi - provincial superior (in the years 1617-1618). The superior general, in fact, promoted the idea of complete separation of the chairs of law and medicine from the Academy; to support which he referred to the example of the university in Pont-à-Mousson. In his opinion, the accumulation of all faculties in one university could result in the violation of school discipline and order. Organizational efforts reached even further, as Michel Oritz from Spain, acting at the request of Eustachy Wołłowicz, the then provincial superior, elaborated the conditions of founding the new faculty of law. The document, once amended, was approved by the superior general of the Order, Mutius Vitelleschi. In 1622 Jan Grużewski, the vice-chancellor of the Jesuit university, received from the superior general of the Order a plan of the foundation, organization and studies of the university in Pont-à-Mousson, together with a directive to introduce a similar structure for the new organizational units in the Academy. See: I. Petrauskienè, Del medicinos ir teises katedru isteigimo Vilniaus Akademijoje XVII a. prazioje, Lietuvos Istorijos Metraštis, 1974, page 104; L. Piechnik, op. cit., t. II, page 158 et seq.

50 J. Bieliński, op. cit., t. II, page 476; S. Bednarski, op. cit., page 291; L. Janowski, op. cit., page 9; J. Wisłocki, op. cit., page 52; L. Piechnik, op. cit., t. II, page 162.

51 V. Bogusis, Medicina Vilniaus Universitete XVI-XVII amžiuje, Mokslas ir Gyvenimas 10 (1979), page 26 et seq.; L. Piechnik, op. cit., t. II, pages 162-163. 
Firstly, the authorities of the Academy turned to the king for the new privilege, finally granted by Ladislaus IV in October 1641. Secondly, the initiators of the foundation of the faculty applied for relevant financial security of the new faculties. The foundation of the chairs lay with the already mentioned court marshal, Kazimierz Lew Sapieha.

\section{The Chair of Roman Law and its Employees}

In this way, almost all conditions necessary for the opening of the new chair were satisfied. The last issue yet to be resolved was who was going to teach at the faculty. The list of Roman (civil) law professors at the Academy of Vilnius is difficult to reconstruct and requires further detailed research ${ }^{52}$. It is known that, owing to the efforts by Sapieha, two Jesuit professors were brought to Vilnius from the university in Ingolstadt, namely: Szymon Dilger - to teach civil law (i.e. Roman law) and Jan Jerzy Schauer - to hold lectures on canon law ${ }^{53}$. Both were German by descent ${ }^{54}$. That it was a momentous phenomenon for the academic circles can be proved by their ceremonial welcome ${ }^{55}$. Szymon Dilger was appointed vice-chancellor of the new faculty ${ }^{56}$. Presumably, only one civil (Roman) law chair was filled ${ }^{57}$. It is not out of the question - it is even highly probable - that Aaron Aleksander Olizarowski taught civil (Roman) law ${ }^{58}$

52 The most extensive sources here are archived documents, which are incomplete. Moreover, the professors had several doctoral degrees and it is difficult to determine in what fields they lectured.

L. Piechnik, op. cit., t. II, page 169. Cf.: J. Jaroszewicz, op. cit., t. III, page 94 et seq.; J. Bieliński, op. cit., t. II, page 476; J. Wisłocki, op. cit., page 52. See: J. Kodrębski, op. cit., page 32.

54 Historia nauki polskiej, t. II, Barok - Oświecenie, ed. B. Suchodolski, Wrocław - Warszawa - Kraków 1970, page 67.

55 Archivum Romanum Societatis Iesu (hereinafter: ARSI) dział Lithuanica 39 f. 98v. It was held by the gateway to the city. After the welcome, a holy mess was celebrated and a reception was organized. The reception was attended by the prelates, gentry and representatives of the magistrate invited by the vice-chancellor. Afterwards, the guests went to the Basilica of St. John, where new professors were promoted to perform the functions of utriusque iuris doctors and doctors of philosophy. One of the professors held a laudatory speech on the founder and the Academy's guests and students gave congratulations. Cf. L. Piechnik, op. cit., t. II, page 169.

56 L. Piechnik, op. cit., t. II, page 171; J. Wisłocki, op. cit., page 52.

57 Historia nauki polskiej, op. cit., t. II, page 214.

58 S. Kot, Aaron Aleksander Olizarowski, profesor prawa Akademii Wileńskiej [in:] Księga Pamiątkowa ku uczczeniu 350 rocznicy założenia Uniwersytetu Wileńskiego, Wilno 1929, page 6. The signature under the letter to the founder of the faculty of law, vice-chancellor of the Grand Duchy of Lithuania, Kazimierz Lew Sapieha, put by Aaron Aleksander Olizarowski, "Iurium Doctor et eorundem in Sapiehanis scholis Professor", provokes the assumption that Olizarowski might have taken up lectures on civil law from the very beginning. See: H. Barycz, Kilka strzępów źródłowych do dziejów literatury polskiej XVI i XII wieku, [in:] Księga pamiątkowa ku czci Konrada Górskiego, Torun 1967, pages 159-162; L. Piechnik, op. cit., t. II, page 172. On the other hand, L. Piechnik was of the opinion that Aaron Aleksander Olizarowski was yet another iuris canonici lecturer, next to Schauer. The lawyer from 
and that the second civil law chair was filled by him as well. Also Jan Świderski is assumed to have been connected with the civil law chair ${ }^{59}$. Perhaps he was a candidate for the post of a professor at the Academy of Vilnius ${ }^{60}$.

Roman law was lectured in the Academy of Vilnius unstoppably until 1655. The year constituted a peculiar censorship in the history of the Almae Mater. The plans of further development of the university were thwarted by the Deluge, which turned the promising University into ruin; the faculty of law burst into flames and its entire property was robbed by Cossack and Russian armies $^{61}$. In accordance with assumptions put forward in the literature on the subject, the period of stagnation in the operation of the faculty of law after the defeats in the 18th-century wars lasted until 1760. Under the reign of King John Casimir, civil law was not lectured at the Academy of Vilnius and lectures on canon law were moved to the faculty of theology ${ }^{62}$.

Neuberg came to the capital of the Grand Duchy of Lithuania in 1644, before the opening of the Faculty of Law (L. Piechnik, op. cit., t. II, page 169-171). See: P. Niczyporuk, Nauczanie prawa rzymskiego..., cit., page 152 .

J. Łukaszewicz, op. cit., t. IV, page 26: “Wydział atoli prawny nie długo się utrzymywał. Po wojnach szwedzkich za Jana Kazimierza nie masz już śladu prawa cywilnego w akademii wileńskiej; prawo zaś kanoniczne wcielono do wydziału teologicznego. Na schyłku atoli panowania Augusta III Jezuici lękając się wyrzutu od narodu, w którym nauki i oświecenie znacznie dźwigać się już z upadku zaczęły, że posiadając fundusze na katedry prawa cywilnego, też na swój użytek obracają, wznowili katedrę prawa cywilnego, wezwawszy na profesora tego prawa Antoniego Ostoję Zagórskiego, sekretarza królewskiego". (The faculty of law did not last long. After the Swedish wars, under the rule of John Casimir, there was no trace of the faculty of law at the Academy of Vilnius; canon law was incorporated into the faculty of theology. In the declining years of the rule of Augustus III, fearing the reproaches of the nation, in which the enlightenment and sciences started to rise from the fall, and accusations that they use for their own benefit the funds received for the chair of civil law, Jesuits established a chair of civil law, calling Antoni Ostoja Zagórski, royal secretary, to perform the function of civil law professor). The standpoint above is shared by S. Bednarski (S. Bednarski, op. cit., page 294) and J. Bieliński (J. Bieliński, op. cit., t. II, page 476); and opposed by L. Piechnik who, referring to the documents obtained tries to prove that the first lectures on civil law were held as early as in 1667. He emphasizes that Roman law was undoubtedly lectured in the 70s (L. Piechnik, op. cit., t. III: Próby odnowy Akademii Wileńskiej po klęskach Potopu i okres kryzysu 1655-1730, Rzym 1987, pages 59-60). Starting 1661, attempts were made to resume lectures on civil law. The initiators of the establishment of the faculty searched for relevant financial security for the new chairs, which was accomplished only in 1665 . Then, the lands that constituted their material basis were returned. Kazimierz Lew Sapieha took care of the foundation of the chairs and of the décor of the lecture room. In 1667, lectures on civil law were resumed. The fragmentariness of the 
First signs of the chair's activity were noticeable in 1674, owing to the financial support granted by Father K. Wojsznarowicz ${ }^{63}$. In the 80s, the civil (Roman) law chair was taken over by Udalrik Franciszek Peier (also known as Peyer or Pejer) ${ }^{64}$. Nevertheless, in the $90 \mathrm{~s}$, he abandoned the position for unknown reasons and the inspector or provincial superior ordered the vicechancellor to look for a competent professor ${ }^{65}$. In this way, Roman law lectures in the Academy were suspended.

In 1699, the chair of civil (Roman) law was taken over by Stanisław Paszkiewicz ${ }^{66}$, alumnus of the Academy of Vilnius, who held lectures until

sources translated does not provide an answer to the question who conducted classes (Historia Collegii Vilnensis 1667, [in:] ARSI, dział Lithuanica 41 f. 382). On March $20^{\text {th }} 1673$, while visiting the Academy, Władysław Rudziński, provincial superior, handed to the vice-chancellor a letter by the general superior of the Order, Jan Pawel Oliwa, dated November $12^{\text {th }} 1672$, reading as follows: "permitto ut in Academia Vilnensi promoveantur discipuli externi ad lauream doctoratus in iure civili et canonico" (Polish translation by L. Piechnik, op. cit., t. III, page 60: "Pozwalam, aby w Akademii Wileńskiej byli dopuszczeni do doktoratu na wydziale prawa cywilnego i kościelnego także eksterni" (I express my consent for awarding doctorates at the faculties of civil and church law to extra-mural students as well). The provincial added: "inteligendum de iis, qui se experimentis probaverint dignos" [this applies to those who prove to be worth it during the exams]). It should be added that theses on civil law were uninterruptedly defended each year until 1760 (I. Petrauskienè, Vilniaus Akademijos Spaustuve 1575-1773, Vilnius 1976, page 215 et seq.). Therefore, there are good reasons to believe that lectures on the subject were held as well. The lack of specific names may prove, on the one hand, that professors had several doctoral titles and it is difficult to determine what they did as lecturers or, on the other hand, that the function might have been performed by people who were not connected with Jesuits and did not do anything great for the history of Vilnius or, at least, for the Academy.

63 S. Bednarski, op. cit., page 292.

64 There is not much information about him. He enjoyed general respect and recognition (J. Bieliński, op. cit., t. III, page 286). Peier held the title of the Doctor of Laws and for twenty years lectured civil law at the Academy (in qua pluribus annis ius civile professus est) - L. Piechnik, op. cit., t. III, page 60. Perhaps he taught both civil and canon law (M. Baliński, op. cit., page 175), although there were signs that he limited himself to civil law only (L. Piechnik, op. cit., t. III, page 60). On Peier see also: K. Čepienè, I. Petrauskienè, Vilniaus Akademijos Spaustuvés Leidiniai 1576-1805, Vilnius 1979, page 114 .

65 It was probably connected with the election, on May $18^{\text {th }} 1684$, of Udalrik Franciszek Peier as a consistory writer. Summary of the deed by the Vilnius Chapter dated May 18th 1684 reads as follows: “[...] Na pisarza konsystorskiego, sede vacante, obrany Franciszek Peyer, dr. ob. pr. Profesor prawa cywilnego w akademji, wielce zasłużony w diecezji [...]" ([...] as a consistory writer, for the sede vacante, was elected Franciszek Peyer, Doctor of Laws, civil law professor at the academy, who rendered great service for the diocese [...]" (J. Kurczewski, Kościót Zamkowy, czyli katedra wileńska w jej dziejowym, liturgicznym, architektonicznym i ekonomicznym rozwoju, cz. III, Streszczenie aktów kapituły wileńskiej, Wilno 1916, page 251). It was an honourable office in Vilnius. Thus, Peier, Doctor of Laws, must have enjoyed respect and recognition in the diocese. Moreover, he became famous as a lecturer at the Academy of Vilnius (J. Bieliński, op. cit., t. III, page 286). He also held the office of mayor (magistratum gesit) - L. Piechnik, op. cit., t. III, page 61; P. Niczyporuk, Nauczanie prawa rzymskiego..., cit., page 155 .

66 Obtained his education in the Academy, where he was granted the title of Master of Arts (philosophy) and Doctor of Laws (L. Piechnik, op. cit., t. III, page 61). On March $26^{\text {th }} 1669$, he presented the theses of his doctoral dissertation: Assertiones canonico - legales de judiciis et processis in causis civilibus et criminalibus (J. Bieliński, op. cit., t. II, page 654). Supervised by the vice-chancellor of the 
his death in $1712^{67}$. Then, between 1712 and 1721, lectures on civil law were abandoned and the chair remained unfilled. The vice-chancellor only received a reprimand from the provincial superior and an order to seek an appropriate professor ${ }^{68}$.

The lectures were suspended probably until 1721, when the vacant chair was taken up by Jerzy Suszycki69. In 1731, the faculty was enriched with a new lecturer, probably Jan Piotr Scheiffers ${ }^{70}$. In 1733, Tomasz Szymak assumed the obligation to hold classes. In 1752, he was replaced by R. D. Tyszko (Tyszka) - professor iuris utriusque et doctor et professor in Academia", who held the office until 1756 ${ }^{71}$. Between 1756 and 1758, lectures on Roman law were again abandoned and resumed only in 1758. Then, the chair was taken over by J. W. Syrpowicz. We do not have details concerning Syrpowicz. It is only known that he conducted classes until $1761^{72}$.

Academy of Vilnius, Krzysztof Łosiewski, doctor of theology and canon law (L. Piechnik, op. cit., t. III, page 61). It is puzzling why Stanisław Paszkiewicz, lecturer on civil (Roman) law did not take the subject for his dissertation from this very law. What made him defend a thesis in canon law? Presumably, no Roman law subject was approved by the professors and Paszkiewicz was unable to find a supervisor (J. Bieliński, op. cit., t. II, page 475). Cf. K. Cepienè, I. Petrauskienè, op. cit., page 113-114.

67 In his testament, Stanisław Paszkiewicz bestowed 73 books to the library in the Academy. Therefore, he was commemorated with a laudatory speech held by a representative of lay students of theology and a funeral sermon. Stanisław Paszkiewicz was a renowned lawyer in Vilnius, even before he was granted the iuris utriusque doctor degree. Maintained good contact with the Jesuit Order and held the office of the royal secretary and notary apostolic. Cf. J. Bieliński, op. cit., t. II, page 654, t. 3, page 280; K. Cepienè, I. Petrauskienè, op. cit., pages 113-114; L. Piechnik, op. cit., t. III, page 61; P. Niczyporuk, Nauczanie prawa rzymskiego..., cit., page 156. students. The manner in which Suszycki held classes is unknown, but he obtained the Doctor of Laws title in 1723 (Laureae Academiae seu Liber continens Ritum Promovendi et Catalogum Promotorum ad Gradum Doctoratus, Licentiatus, Magisterii et Bacalaureatus in Alma Academia Vilnensi Soc. Jesu comparatus et ordinatus Anno 1723 (hereinafter: Laureae), Biblioteka Wileńska rkps F2 DC1, f. 103). These are all the skimpy pieces of information about him available. See: L. Piechnik, op. cit., t. III, page 62; P. Niczyporuk, Nauczanie prawa rzymskiego..., cit., page 156 et seq.

70 Came to Vilnius from abroad, but his city or country of origin are unknown. Scheiffers was granted the title of the Doctor of Laws at the University in Vilnius in 1731. Unfortunately, these are all the skimpy pieces of information about him available. See: L. Piechnik, op. cit., t. III, page 62.

71 In his records for the Holy See in 1773, Bishop Michał Zienkowicz wrote: regens, sacerdoces saecularis, theologus absolutus, iuris utriusque doctor et in Academia Vilnensi iuris civilis actualis professor (Relationes status Dioecesium in Magno Ducatu Lituaniae, t. I, ed. P. Rabikauskas, Romae 1971, s. 127). Information on how long Tomasz Szymak taught Roman law is unknown. Cf.: R. D. Tyszko (Tyszka) is probably Dec. Daniel Tyszka, artium et philosophiae doctor, who was granted the Doctor of Laws degree in 1749, (R. Plechaitis, Stopnie naukowe w dawnym Uniwersytecie Wilenskim, [in:] Studia z dziejów Uniwersytetu Wileńskiego 1579-1979, Kraków 1979, page 48). Cf. P. Niczyporuk, Nauczanie prawa rzymskiego..., cit., page 157.

72 J. Bieliński states that he held lectures in Latin for year one, following the example of other European universities, and in Polish for year two. Obtained doctoral degree in civil and canon 
In 1759, civil law was lectured in Vilnius by the royal secretary, Antoni Ostoja Zagórski ${ }^{73}$. However, he did not hold the office for long since he was dismissed in an atmosphere of intrigues, which he initiated himself. He was replaced in 1761 by two professors: Kozaryn (about whom information is skimpy) and the attorney of the Vilnius consistory, Andrzej Wieczorkowski ${ }^{74}$. Kozaryn worked for a year only and was replaced by a cathedral master of celebration and vice-regent (becoming regent in 1764) of the Diocesan Seminary, Augustyn Dąbrowski (Dombrowski) ${ }^{75}$. Theoretically, he held the office in the chair until 1764, when the last civil law lecturer before the great reform of the Academy, Pawel Meier (Majer), appeared76. The term "theoretically" is by no means accidental here because, by the time mentioned, both scholars exchanged in giving lectures on civil law ${ }^{77}$. Paweł Meier kept the post until 1771. When he resigned, lectures on civil law were abandoned. It was a long break, lasting ten years. In the meantime, many changes were introduced in education: the Jesuit Order was dissolved and the Commission of National Education was set up. It was a harbinger of a thorough reform and great transformations, including in the system of education of the Almae Matris. The Academy of Vilnius returned to the arena of academic and cultural life with new enthusiasm in 1781, as the Principal School of the Grand Duchy of Lithuania. Its vicechancellor was Marcin Poczobut. Between 1803 and 1832, the school existed as the Imperial University of Vilnius ${ }^{78}$. In the opinion of L. Janowski, there was no major difference between the Principal School and the later Imperial

law on September $16^{\text {th }} 1760$. In his speech, held in 1761: "The speaker about the goodness, the need and the usefulness of jurisprudence" he emphasised the significance of Roman law for almost the entire human nation, [as] the law collected from the oldest wisdom of all ages and times, which aims to eradicate churlishness and bind opinions, thoughts and hearts with a single knot ("całego prawie narodu ludzkiego z jak najstarodawniejszej wszystkich wieków i czasów mądrości zebranym jest prawem dla wykorzenienia grubiaństwa oraz dla zjednoczenia w jedno jednym niby węzłem wszystkie wszystkich narodów zdania, myśli i serca") - quotation from J. Sondel, Ze studiów nad prawem rzymskim w Polsce w okresie Oświecenia, Warszawa-Kraków 1988, page 56. The preface with which he used to inaugurate his lectures (O zacności, potrzebie i pożytku jurysprudencji) was published by his students: Jerzy andi Ignacy Zubowski 21.VII.1761 roku - See: J. Bieliński, op. cit., t. III, page 360. Por. J. Łukaszewicz, op. cit., t. IV, page 27; L. Piechnik, op. cit., t. III, pages 62-63.

L. Piechnik, op. cit., t. III, page 63; M. Dyjakowska, op. cit., page 113 et seq. together with the literature quoted.

74 L. Piechnik, op. cit., t. III, pages 64-66.

75 Granted doctorate in canon law in 1763, a year later obtained the title of the doctor of theology. Considered an expert in his field, trustworthy and reliable, assessed very highly in terms of the level of the lectures held. L. Piechnik, op. cit., t. III, pages 66-67. O Dąbrowskim; see also: K. Cepiene, I. Petrauskienè, op. cit., pages 217, 391, 496.

76 Historia nauki polskiej, op. cit., t. II, page 68; L. Piechnik, op. cit., t. III, page 67.

77 L. Piechnik, op. cit., t. III, page 67. See: także: K. Ċepiene, I. Petrauskienè, op. cit., pages 217, 325-326.

78 L. Piechnik, K. Puchowski, Słowo wstępne [in:] Księga pamiątkowa ku czci 400-lecia założenia i 75-lecia wskrzeszenia Uniwersytetu Wileńskiego, Kraków 1996, page 7. 
University ${ }^{79}$. The University was a continuation of the School and a new name was by no means a revolution. A proof here can be the number of professors. S. Bednarski abides by and extends the statement of L. Janowski in this scope ${ }^{80}$. The Principal School was a continuator of the Jesuit Academy and its activity was based on the foundation laid by Jesuits.

\section{Academic Works on Roman Law}

The traces left constitute evidence of reliable academic work of all professors. Aaron Aleksander Olizarowski published a treatise entitled Assertiones ex Iurisprudentia in 1647, approved by the vice-chancellor of the Academy, Benedict de Soxo and the dean of the faculty of law, Szymon Dilger. Later, in 1651, he published in Gdańsk the work of his life: De politica hominum societate systematic lecture on the society and the country ${ }^{81}$. Students also wrote dissertations under the supervision of the aforementioned professors. The figure of André Marquart should be mentioned here, who was granted a doctorate in 1647 for his thesis: Dissertatio juridica e jure canonico, civili et Regio Poloniae MD Lithuaniae nec non saxonicco et municipali Magdeburgensi dicisa, devoted to inheritance law, written under the supervision of Jan Schauer ${ }^{82}$. In 1650, yet another dissertation was published in the University printing house, this time devoted to civil law. The dissertation by Jan Marquart, De damno injuriae, was written under the auspices of Szymon Dilger ${ }^{83}$.

What is also worth mentioning is the dissertation by Benedict de Soxo vice-chancellor of the Academy, targeted at young people studying law and entitled: Claves juris Accademicis Vilnensibus... porrectae, published in $1648^{84}$. In four chapters, the author presents definitions, types of law, sources of Roman law, canon law and local law. The work contains analyses of the bases of natural and positive law: canon, civil Roman law and the law of Rzeczpospolita. It is known for sure that Benedict de Soxo did not teach Roman law, however, as the vice-chancellor, he was strongly connected with the faculty of law ${ }^{85}$.

79 L. Janowski, op. cit., page 8.

80 S. Bednarski, op. cit., page 294.

81 E. Jarra, Aleksander Olizarowski, jako filozof prawa [in:] Księga pamiątkowa celem uczczeniu 350 rocznicy założenia Uniwersytetu Wileńskiego, Warszawa 1931, pages 33-72.

82 L. Piechnik, op. cit., t. II, page 172. See also: J. Kodrębski, op. cit., page 32.

83 S. Kot, op. cit., page 5; L. Piechnik, op. cit., t. II, page 172.

84 J. Brown, Biblioteka pisarzów asystencji Polskiej Towarzystwa Jezusowego, trans. Wł. Klejnowski, Poznań 1862, page 388; I. Petrauskienè, Del medicinos ir teises katedru isteigimo Vilniaus Akademijoje XVII a. prazioje, cit., pages 95-96.

85 It is possible that he taught canon law. See: M. Baliński, op. cit., page 147; J. Bieliński, op. cit., t. II, page 475; S. Załęski, Jezuici w Polsce, t. II, Lwów-Kraków 1900-1905, page 640; A. Petrani, Nauka prawa kanonicznego w Polsce w XVIII i XIX wieku, Lublin 1961, page 204. 


\section{Doctorate of Laws (utriusque iuris) at the Academy of Vilnius}

The title of doctorate was the crowning achievement in legal education. Following the example of other universities, the Academy of Vilnius granted a combined title of doctor "of laws": civil law and canon law ${ }^{86}$. However, Academia Vilnensis constituted an exception to the rule among Polish university since, next to the doctorate of laws degree, it also awarded doctorates in canon law only ${ }^{87}$. Presumably, no civil law doctorates were granted at the Academy of Vilnius and graduates in civil law could only obtain the bachelor's degree ${ }^{88}$.

Doctorates could be applied for by future professors of law in the first place $^{89}$. The titles were also granted to high church dignitaries who held public offices $^{90}$. Finally, the Doctor of Laws degree was awarded to Jesuits teaching

86 A. Niczyporuk, Promocje doktorskie obojga praw w Akademii Wileńskiej, Miscelanea historio-iuridica 2 (2004), page 18 et seq.

87 R. Plečkaitis, Stopnie naukowe w dawnym Uniwersytecie Wileńskim, cit., page 33; L. Piechnik, op. cit., t. II, page 81; M. Dyjakowska, op. cit., page 193 et seq. together with the literature quoted.

88 R. Plečkaitis, Moksliniai laipsniai senajame Vilniaus Universitete [in:] “Mokslas ir Gyvenimas” 1 (1975), page 24; idem, Stopnie naukowe..., op. cit., page 33; L. Piechnik, op. cit., t. II, page 81; ibidem, op. cit., t. IV: Odrodzenie Akademii Wileńskiej w latach 1730-1733, page 144. However, L. Piechnik, (op. cit., t. II, page 186) was of the opinion that doctors of civil (Roman) law were also promoted in the Academy of Vilnius.

89 The first law teacher employed at the Academy, who was granted the academic degree of the doctor of civil (Roman) law and canon law, was probably Stanisław Paszkiewicz, who obtained his title on the basis of the dissertation entitled: Assertiones canonico-legales de judiciis et processis in causis civilibus et criminalibus. The award took place on March $26^{\text {th }} 1699$, and the supervisor of his thesis was the vice-chancellor of the Academy of Vilnius, Krzysztof Losiewski, doctor of theology and canon law. (J. Bieliński, op. cit., t. II, page 654; K. Estreicher, Bibliografia polska, t. XXIV, Kraków 1912, page 124; K. Ceepienè, I. Petrauskienè, op. cit., page 113-114; L. Piechnik, op. cit., t. III, page 61). On June $8^{\text {th }} 1723$, the $u$ triusque iuris doctorate was awarded to Jerzy Suszycki, and in 1731 - to Jan Piotr Scheiffers. The next doctorate of both laws title was awarded to utriusque iuris professor, Tomasz Szymak, on October $8^{\text {th }} 1773$. Among other iuris utriusque doctors were also: Daniel Tyszka, Antoni Ostoja Zagórski and Augustyn Dąbrowski (Dombrowski). On November $24^{\text {th }} 1763$, Paweł Meier (Majer), civil (Roman) law lecturer, was promoted. He was the last utriusque iuris doctor in the Academy of Vilnius among the iuris civilis professors. See: R. Plečkaitis, Stopnie naukowe..., page 47 et seq. Cf. Historia nauki polskiej, cit., t. II, page 68; L. Piechnik, op. cit., t. III, page 67.

90 On December 8th 1708, the title of utriusque iuris doctor was granted to Aleksander Jan Żebrowski - parochus Solensis; in the next year, to Ernest Kazimierz Delatour, cathedral canon priest of Luck and in 1727 (November Nones) and to Józef Puzyna, cathedral canon priest of Vilnius. In 1730, on the eve of June Nones, Antoni Źółkowski, archdeacon of Belarus was granted the title. In 1731, the same title of utriusque iuris doctor was granted to Ludwik Józef Dawidowski, superior of the seminary in Vilnius and, in the next year, to Jakub Adembski, cathedral canon in Chełmno. On September $8^{\text {th }} 1739$, Karol Karp, the archdeacon of Samogitia, was promoted to become the utriusque iuris doctor and then, in November 1741, Antoni Kraws - superior of the diocesan seminary. A year later, the following persons were awarded the utriusque iuris doctor titles: Dowgiało Zawisza - canonicus Livoniensis (January $9^{\text {th }}$ ) and prelate, Franciszek Antoni Kononowicz (May 17th). Further utriusque iuris doctor titles were granted to church dignitaries - in 1775, on the eve of October Nones, to Mikołaj Tyszkiewicz, cathedral canon of Vilnius and on the $8^{\text {th }}$ day of July Calends, to Jan Lopaciński, MDL secretarius. Presumably, Jan Łopuciński future Bishop of Samogitia also became the utriusque iuris doctor. Later, in 1763, on the third day 
canon law ${ }^{91}$. In the Academy of Vilnius, just like in other universities, the right to grant academic degrees and promote its own doctors was the most significant privilege of the rank. Owing to the privilege, the university was granted prerogatives which made it equal with other schools of higher education of the Christian world ${ }^{92}$. Academia Vilnensis vaunted the right starting in 1641, which was several dozen years after the foundation of the Almae Mater in Vilnius. Although, pursuant to the papal bull of pope Gregory XIII dated October $29^{\text {th }} 1579$, the Academy was granted the right to promote doctors of philosophy, theology, law and medicine ${ }^{93}$, still, the use of the right bestowed needed to be confirmed by the king ${ }^{94}$. It was only King Ladislaus IV who, in October 1641, issued a relevant privilege to the Almae Mater in Vilnius, authorizing it to promote doctors of law and medicine as, pursuant to the privilege issued by King Stephen Báthory on July $7^{\text {th }} 1578$, the university had no such right ${ }^{95}$. All in all, between 1583 and 1781, 36 canon and civil law doctorates or bachelor's degrees were granted at the Academy of Vilnius and 113 degrees in canon law ${ }^{96}$.

of the June Calends, the title of a utriusque iuris doctor was granted in the Academy of Vilnius to Stefan Giedroyć, Suffragan Bishop for Belarus. On the $17^{\text {th }}$ day of the January Calends, the same title was granted to Michał Chomicki, Suffragan Bishop for Samogitia and on April Nones - to Jan Józef Wawrzecki, vicepraefectus Orsensis. Until the end of its existence, Academia Vilnensis promoted numerous church dignitaries. In December 1769, Józef Leon Łopaciński, cathedral canon in Miedniki, later Bishop, was granted the title of a utriusque iuris doctor and in February 1772, Józef Kossakowski, prelate guardian of the Vilnius Cathedral. Among other persons promoted in 1773 were: Paweł Ksawery Brzostowski - notarius MDL supremus (July) and Jerzy Polubiński - canon of the Vilnius Cathedral (November). In 1774, titles of a utriusque iuris doctor were granted to: Józef Korsak - canon of the Smolensk Cathedral (April) and Sebastian Jankowski - prelate of the Samogitia Cathedral (June). In January 1776, the tile was awarded to Józef Rogaliński - vice-chancellor of the Academy of Poznań. On January $23^{\text {rd }} 1778$, Adam Koscis, praelatus cancellarius Livoniensis joined the circles of the persons promoted and, on September $3^{\text {rd }} 1779-$ Ksawery Kieszkiewicz, head of the diocesan seminary. See: L. Piechnik, op. cit., t. III, page 67; R. Plečkaitis, Stopnie naukowe..., page 48 et seq.

91 L. Piechnik, op. cit., t. II, page 81.

92 H. Gmiterek, Promocje doktorskie w Akademii Zamojskiej, [in:] W kręgu akademickiego Zamościa, ed. H. Gmiterek, Zamość 1996, page 225.

93 H. Gmiterek, op. cit., page 226; L. Piechnik, op. cit., t. II, page 157.

94 H. Gmiterek, op. cit., page 226; M. Dyjakowska, op. cit., page 188 together with the literature quoted.

95 L. Piechnik, op. cit., t. II, page 157.

96 R. Plechaitis, op. cit., page 34. Cf. I. Jaroszewicz, op. cit., page 224-226; J. Kodrębski, op. cit., page 32. As stated by L. Piechnik, following the foundation of the Academy, until 1773, 46 academic degrees in canon and civil law (doctorates and bachelor's degrees) were granted as well as 97 degrees in sole canon law, see: L. Piechnik, op. cit., t. II, page 185. Research on the history of the Vilnius Mater is made easier owing to a very valuable document - manuscript of the registration of academic degrees granted by the Academy - Laurae Academicae seu Liber continens Ritum Promovendi et Catalogum Promotorum ad Gradum Doctoratus, Licentiatus, Magisterii et Bacalareatus in Alma Academia Vilnensi Societatis Iesu comparatus et ordinatus Anno 1650. The document lists almost all persons promoted in the Academy, starting from its establishment until the dissolution 
The award of the combined title of a Doctor of Laws: civil law and canon law, was preceded by a complicated promotional procedure. The ceremonies looked similar to those at other universities ${ }^{97}$. However, in the Academy of Vilnius, usually modest promotions were organized, called privatum ${ }^{98}-$ which might have been due to the religious nature of the university.

\section{Substance of Lectures on Roman Law}

The content of lectures on Roman Law can be reconstructed from the work of a professor of law and outstanding educator, Jakub Staszewski. He wrote an introduction to canon and civil (Roman) law for beginner students of law and published it under the title: Aliuid iuris brevem notitiam iuris canonici continens, madum simul allegandi ex utroque iure, breviaturas legendi iuris canonici regulasque eiusdem iuris ordine atphabetico exhibens. In gratiam studiosorum iuris quodam Soc. Jesu theologo luci datum cum facultate superiarum (Imprimatur. Carolus episcopus m.p. Vilnae, typis academicis Socieratis Iesu. AD. 1728) ${ }^{99}$. Aliquid iuris is an important source for those who wish to learn the curricula of Roman and canon law lectures. Not only did Staszewski teach how to quote and decipher abbreviations while referring to other works, but also explained peculiar expressions and basic legal terms. Further in the text of his introduction, he discussed Roman civil law. He emphasized that of the five parts of the work (Institutiones; Digestum; Codex; Authenticum; Libri Feudorum), the first one: Institutiones seu In-

of the Jesuit Order in 1773. It was probably reconstructed after 1650 on the basis of fragmentary sources, as the original manuscript was lost during the wars of the mid- $17^{\text {th }}$ century. Entries in the book were made by the secretary of the university, who, apart from the date of the award of the academic degree and personal data, also inserted information about the activity (academic, church, pedagogical etc.) of the person promoted. It is probably owing to the secretary that the reconstruction of the document concerning the award of the academic titles by the Academy until mid-17th century was possible. Nevertheless, the document does not include names of all the persons promoted. The gaps probably concern the $16^{\text {th }}$ and the first half of the $17^{\text {th }}$ century as follows from the remarks of the author of Laurae Academicae: "Multorum scire nomina non potui; quos e variis scriptis collectis habere potui, hic oblivioni eripere volui" ("Wielu nazwisk nie mogłem poznać. Te, które mogłem zebrać z różnych pism, chciałem uchronić od zapomnienia" - translation into Polish by L. Piechnik, op. cit., t. II, page 186) (I was unable to get to all the names. The ones I collected from numerous letters, I wished to rescue from oblivion). In the opinion of L. Piechnik, the document, currently stored in the Library of the University in Vilnius (rkps F2 DC1), constitutes the basic source of information within the scope of study aids in the Academy - L. Piechnik, op. cit., t. II, page 185. The list of persons promoted presented by R. Plečkaitis was based on the said document (Stopnie naukowe..., page 38-58).

97 L. Piechnik, op. cit., t. II, page 182 et seq. The promotion procedure in the Zamość Academy was described in detail by M. Dyjakowska, op. cit., page 194 et seq. together with the literature quoted.

98 R. Plechaitis, op. cit., page 10; M. Dyjakowska, op. cit., page 203 et seq.

99 K. Estreicher, Bibliografia polska, t. XII, Kraków 1891, page 117. 
stituta Iustiniani was basically taught at the Academy. Nonetheless, he briefly described the remaining four as well as their relation to Institutiones. It should be noted that the work by Staszewski, who lectured law at the Academy for 14 years, was an excellent - concise and transparent - introduction to legal sciences.

The lecturer of civil law also paid attention to the principles of common law and statute law applicable in Poland, that is, the land law of the gentry; city privileges stemming from German law as well as the statutes of districts and feudal duchies. At the core of the lectures on Roman law lay the Institutiones of Justinian $\mathrm{I}^{100}$. As suggested by the majority of copies of the work at the academic library, the work was the basic reading of the students of law. Beyond doubt, much richer in content was the collection of the specialist library of the professor of the subject, which he had in his flat. Among the works collected by him were: Digestum Vetus Justiniani; Digestum Novum Justiniani; by Paulus Castrensis, Jus civile - 6 copies; Codex Theodosianus, and (when it comes to commentators of the Justinian's Institutiones) Consilia by the famous lawyer, Baldi de Baldis (1319-1400).

When it comes to dictionaries, there was the Encyklopedia juris universi (Coloniae 1638) by an eminent protestant lawyer, Ulrich Hunnius (1583-1636). One could also find there many a civil law treatise, among others, De jure belli et pacis' by Hugo Grotius (Parisiis 1625) and Commentary to the Justinian's Institutiones published in 1663: De Jure Personarum..., by Teodor TyszkiewiczSkuminowicz (1663).

\section{Final Remarks}

The University of Vilnius became a multi-national school, a magnet that attracted both enlightened minds and famous professors from almost all over Europe, and crowds of young Lithuanians, Poles, Belarusians, Ukrainians and Latvians willing to study within its confines. The University enjoyed respect and recognition across Europe, rivalling the best European schools of the type. Following its establishment, the University experienced changing fortunes. The times of glory and bloom intertwined with moments of crises and historical storms, the school stuck by Rzeczpospolita through thick and thin and came through countless ups and downs, ending and restarting its activity many a time.

The presence of Roman law at the Academy of Vilnius and in its circles provokes the opinion that discipline was an important element of the academic

100 L. Piechnik, op. cit., t. IV, page 193. 
life of the then circles. Although Moroz was the only specialist in Romance studies at the Academy / University, Roman law played a significant role in educating lawyers.

\section{Bibliography}

Archivum Romanum Societatis Iesu, dział Lithuanica 39 f. 98v.

Baliński M., Dawna Akademia Wileńska, Petersburg 1862.

Balzer O., Przygodne słowa, Lwów 1927.

Bardach J., Geneza romanizacji II Statutu litewskiego, [in:] Dawne prawo i myśl prawnicza (poświęcone pamięci Wojciecha Marii Bartla), Kraków 1995.

Bardach J., Statuty Litewskie a prawo rzymskie, Warszawa 1999.

Bardach J., Statuty litewskie w ich kregu kulturowym, [in:] O dawnej i niedawnej Litwie, Poznań 1988.

Barycz H., Kilka strzępów źródłowych do dziejów literatury polskiej XVI i XII wieku, [in:] Księga pamiątkowa ku czci Konrada Górskiego, Torun 1967.

Beauvois D., Szkolnictwo polskie na ziemiach litewsko-ruskich 1803-1832, t. I, Uniwersytet Wileński, Rzym - Lublin 1991.

Bednarski S., Dwieście lat Wileńskiej Akademii Jezuickiej 1570-1773. Próba syntezy [in:] Pamiętnik VI powszechnego zjazdu historyków polskich w Wilnie 1720 września 1935 r., part 1, Lwów 1935.

Bibliografia Literatury Polskiej - Nowy Korbut, t. III. Piśmiennictwo Staropolskie, opr. R. Pollak, T. Witczak, D. Maniewska, J. Cybertowicz, Warszawa 1965.

Bieliński J., Uniwersytet Wileński (1579-1831), t. II, Kraków 1900.

Bogusis V., Medicina Vilniaus Universitete XVI-XVII amziuje, Mokslas ir Gyvenimas 10 (1979).

Bossowski F., Nowela Justyniana 115 - Statut Litewski i R. IV. Art. 13 (14), Statut Litewski II i III R. VIII Art. 7 - T. X. Cz. I Art. 167, [in:] Ksiegga pamiątkowa ku uczczeniu czterechsetletniej rocznicy wydania pierwszego Statutu litewskiego, pod red. S. Ehrenkreutza, Wilno 1935.

Brown J., Biblioteka pisarzów asystencji Polskiej Towarzystwa Jezusowego, trans. Wł. Klejnowski, Poznań 1862.

Bukowska G., Tomasz Drezner, polski romanista XVII wieku i jego znaczenie dla nauki prawa w Polsce, Warszawa 1960.

Čepienė K., Petrauskienè I., Vilniaus Akademijos Spaustuvès Leidiniai 1576-1805, Vilnius 1979.

Davis N., Boże igrzysko. Historia Polski, Kraków 1997.

Decisiones de rebus in sacro auditorio Lituanico ex appelatione iudicatis, Kraków 1563.

Dyjakowska M., Prawo rzymskie w Akademii Zamojskiej w XVIII wieku, Lublin 2000. 
Ehrenkreutz S., Zagadnienia wptywu prawa rzymskiego na Statuty litewskie, [in:] Pamiętnik VI Powszechnego Zjazdu Historyków Polskich w Wilnie, t. I, Referaty, Lwów 1935.

Estreicher K., Bibliografia polska, t. XII, Kraków 1891.

Estreicher S., Kultura prawnicza w Polsce XVI wieku, [in:] Kultura staropolska, Kraków 1932.

Fijałkowski T., Piotr Rojzjusz - polski romanista XVI wieku, [in:] Z dziejów polskiej kultury umysłowej w XVI i XVII wieku, W. Voisé (red.), Wrocław-WarszawaKraków-Gdańsk.

Fijałkowski T., Piotr Rozjusz w opiniach współczesnych i potomnych, Sprawozdanie z Czynności i Posiedzeń Łódzkiego Towarzystwa Naukowego 26.5 (1972).

Gmiterek H., Promocje doktorskie w Akademii Zamojskiej, [in:] W kregu akademickiego Zamościa, pod red H. Gmiterka, Zamość 1996.

Godek S., Prawo rzymskie w dawnej Rzeczypospolitej. Przegląd stanu badań, CPH 53 (2001), f. 2, p. 48.

Godek S., Prawo rzymskie w Polsce przedrozbiorowej w świetle aktualnych badań, Zeszyty Prawnicze 13.3 (2013).

Historia nauki polskiej, t. II, Barok - Oświecenie, pod red. B. Suchodolskiego, Wrocław - Warszawa - Kraków 1970.

Janowski L., Historiografia Uniwersytetu Wileńskiego, part 1, Wilno 1921.

Jaroszewicz J., Obraz Litwy pod względem jej cywilizacji od czasów najdawniejszych do końca wieku XVI, Wilno 1844, t. II.

Jarra E., Aleksander Olizarowski, jako filozof prawa, [in:] Księga pamiatkowa celem uczczeniu 350 rocznicy założenia Uniwersytetu Wileńskiego, Warszawa 1931.

Jobert A., Luther à Mohyla, Paryż 1974.

Kodrębski J., Prawo rzymskie w Polsce XIX wieku, Łódź 1990.

Kot S., Aaron Aleksander Olizarowski, profesor prawa Akademii Wileńskiej, [in:] Księga Pamiątkowa ku uczczeniu 350 rocznicy założenia Uniwersytetu Wileńskiego, Wilno 1929.

Kruczkiewicz B., De Royzii vita operibusque, [in:] Petri Royzii Maurei Alcagnicensis Carmina, Pars I. Carmina maiora continens, ed. B. Kruczkiewicz, Cracoviae 1900.

Kruczkiewicz B., Royzyusz. Jego żywot i pisma, Rozprawy Wydziału Filologicznego Akademii Umiejętności w Krakowie 27 (1897).

Kurczewski J., Kościół Zamkowy, czyli katedra wileńska w jej dziejowym, liturgicznym, architektonicznym i ekonomicznym rozwoju, cz. III, Streszczenie aktów kapituły wileńskiej, Wilno 1916.

Lappo I., Litowskij statut 1588 goda, t. I, part 2, Kowno 1936.

Laureae Academiae seu Liber continens Ritum Promovendi et Catalogum Promotorum ad Gradum Doctoratus, Licentiatus, Magisterii et Bacalaureatus in Alma Academia Vilnensi Soc. Jesu comparatus et ordinatus Anno 1723, Biblioteka Wileńska rkps F2 DC1, f. 103. 
Lyavshuk V., Stephan Bathory and the Jesuits in Grodno: First Attempt to Found a Collegium, Medieval and Early Modern for Central and Eastern Europe 2 (2010).

Łukaszewicz J., Historia szkót w Koronie $i$ w Wielkim Księstwie Litewskim od najdawniejszych czasów aż do roku 1794, t. IV, Poznań 1851.

Materyały do dziejów piśmiennictwa polskiego i biografii pisarzów polskich, ed. T. Wierzbowski, t. I. 1398-1600, Warszawa 1900.

Niczyporuk P., Nauczanie prawa rzymskiego w Akademii Wileńskiej [in:] Wielokulturowość polskiego pogranicza. Ludzie - Idee - Prawo. Materiaty ze Zjazdu Katedr Historycznoprawnych Augustów 15-18 września 2000 r., pod red. A. Lityńskiego i P. Fiedorczyka, Białystok 2003.

Niczyporuk P., Predarea dreptului roman la Universitatea din Vilnius [in:] Ad honorem Prof. univ. dr. Ion Dogaru: studii juridice alese / volum coordonat de prof. univ. dr. Adrian Năstase; traducera Adriana Uliu; Bucureşti 2005.

Niczyporuk P., Promocje doktorskie obojga praw w Akademii Wileńskiej, Miscelanea historio-iuridica 2 (2004).

Niczyporuk P., Преподавание римского права в Вильнюсской Академии [in:] 3борник радова Правног факултета у Новом Саду. Recueil des travaux XXXVIII, 1, t. I (2004), IX Колоквиј Романиста Централне и Источне Европе и Азије, Нови Сад 24 октобра 2002, Нови Сад 2004.

Nowodworski M., Encyklopedia kościelna, Warszawa 1899, t. XXIII.

Petrani A., Nauka prawa kanonicznego w Polsce w XVIII i XIX wieku, Lublin 1961.

Petrauskienè I., Del medicinos ir teises katedru isteigimo Vilniaus Akademijoje XVII a. prazioje, Letuvos Istorijos Metraštis, 1974.

Petrauskienè I., Vilniaus Akademijos Spaustuve 1575-1773, Vilnius 1976.

Piechnik L., Dzieje Akademii Wileńskiej, t. II: Rozkwit Akademii Wileńskiej w latach 1600-1655, Rzym 1982; t. III: Próby odnowy Akademii Wileńskiej po klęskach Potopu i okres kryzysu 1655-1730, Rzym 1987; t. IV: Odrodzenie Akademii Wileńskiej w latach 1730-1733, Rzym 1990.

Piechnik L., Puchowski K., Słowo wstepne [in:] Ksiega pamiątkowa ku czci 400-lecia założenia i 75-lecia wskrzeszenia Uniwersytetu Wileńskiego, Kraków 1996.

Plečkaitis R., Moksliniai laipsniai senajame Vilniaus Universitete [in:] "Mokslas ir Gyvenimas" 1 (1975).

Plečkaitis R., Stopnie naukowe w dawnym Uniwersytecie Wileńskim, [in:] Studia z dziejów Uniwersytetu Wileńskiego 1579-1979, Kraków 1979.

Puchowski K., Jezuickie kolegia szlacheckie Rzeczypospolitej Obojga Narodów: studium z dziejów edukacji elit, Gdańsk 2007.

Rabikauskas P., Teisé ir medicina Vilniaus Akademijoje, Aidai 3 (1975).

Relationes status Dioecesium in Magno Ducatu Lituaniae, t. I, ed. P. Rabikauskas, Romae 1971.

Šidlauskas A., Zarys historiografii Uniwersytetu Wileńskiego, Studia z dziejów Uniwersytetu Wileńskiego 1579-1979, ZN UJ 554 Prace Hist. (1979), f. 64. 
Skubała-Tokarska Z., Tokarski Z., Uniwersytety w Polsce. Rys historyczny, Warszawa 1972.

Sondel J., Zawsze wierni. Uniwersytet Jagielloński a Kościót rzymskokatolicki, Kraków 2006.

Sondel J., Ze studiów nad prawem rzymskim w Polsce w okresie Oświecenia, WarszawaKraków 1988.

Tamošiūnienè A., Eilès lediniam kraštui. Sarmatijos paveikslas Petro Roizijaus poezijoje, DARBAI ir DIENOS 44 (2005).

Tamošiūnienè A., Pilietiškumas Petro Roizijaus ( 1505-1571) küryboje, PhD thesis published, Kaunas 2007.

Taubenschlag R., Eiflus der römischen Rechts in Polen, [in:] Ius Romanum Medii Aevi, c. 5, 1962, nr 7-9.

Taubenschlag R., Gli influssi romano-bizantini sul secondo Statuto lituano, SDHI 1(1937).

Taubenschlag R., La stiria delle recezione del diritto romano in Polonia fino alla fine del secolo XVI, Bolonia 1939, reprint [in:] Europa e il Diritto Romano. Studi in memoria di Paolo Koschaker, t. I, Milano 1953 (1954).

Taubenschlag R., Wplywy rzymsko-bizantyjskie w drugim Statucie litewskim, Lwów 1933.

Tazbir J., Piotr Roizjusz, [in:] Polski Słownik Biograficzny, ed. H. Markiewicz, t. XXXI, Wrocław 1988-1989.

Vetulani A., Opory wobec prawa rzymskiego w dawnej Polsce, "Annalecta Cracoviensia" 1(1969).

Wisłocki J., Prawo rzymskie w Polsce, Warszawa 1945.

Załęski S., Jezuici w Polsce, t. I-II, Kraków 1900-1905. 